\title{
Consanguineous Marriages and Their Association With Women's Reproductive Health and Fertility Behavior in Pakistan: Secondary Data Analysis From Demographic and Health Surveys, 1990-2018
}

Sarosh lqbal

University of the Punjab

Rubeena Zakar

University of the Punjab

Florian Fischer ( $\nabla$ florian.fischer1@charite.de)

Charite Universitatsmedizin Berlin https://orcid.org/0000-0002-4388-1245

Muhammad Zakria Zakar

University of Okara

\section{Research article}

Keywords: Consanguinity, Consanguineous union, Reproduction, Sexual and reproductive health

Posted Date: October 1st, 2020

DOI: https://doi.org/10.21203/rs.3.rs-70736/v1

License: (c) (1) This work is licensed under a Creative Commons Attribution 4.0 International License. Read Full License

Version of Record: A version of this preprint was published at BMC Women's Health on April 14th, 2022. See the published version at https://doi.org/10.1186/s12905-022-01704-2. 


\section{Abstract}

Background: Pakistan has been showing consistently the highest prevalence of consanguinity. The popularity of consanguineous marriages is not declining in the country, because of social, cultural, and religious beliefs as well as economic advantages. However, couples also face various health related implications, such as poor pregnancy outcomes or multiple reproductive and fertility consequences, having adverse effects on mothers and their children. This research investigated the trend of consanguineous marriages and their association with women's reproductive health and fertility behavior in Pakistan from 1990 to 2018.

Methods: This study is based on a secondary data analysis, using all four waves of the Pakistan Demographic Health Surveys carried out during 1990 to 2018. The analysis is limited to women aged 15-49 years, who had given birth in the previous five years preceding each survey. Descriptive statistics, bivariable and multivariable logistic regression analysis was performed to determine the association of consanguinity with multiple characteristics related to socio-demographics, co-variates and women's reproductive health and fertility behaviors.

Results: The findings revealed an high but overall stable trend of consanguinity prevalence of about $63 \%$ during the last three decades. Consanguineous marriages were more prevalent amongst young and uneducated women, living in rural areas, with poorer wealth status and having less exposure of mass media to access information. A strong association of consanguinity was observed with women's reproductive health and fertility behavior, particularly for women who gave first birth at younger age, had multi-gravida pregnancies, multi-parity, pregnancy termination, ANC visits and higher fertility.

Conclusion: Consanguineous marriages are predominant in the patriarchal society of Pakistan. Findings revealed that consanguinity contributes significantly to women's reproductive health and fertility behaviors. Appropriate counselling, educational and health promotional programs related to consanguinity should be designed and launched at community level to raise awareness about risks towards women's reproductive health and fertility.

\section{Background}

Consanguinity is termed as a wedlock or marriage between close blood relations or biological kin. Consanguineous marriages have been very common since the early existence of humanity. According to a rough estimate, nearly one billion (20\%) of the global population live in communities with a preference for consanguineous marriages [1, 2], predominantly in Muslim countries of the Middle East, Africa and South Asia [3, 4]. With 65\%, Pakistan has one of the highest rates of cousin marriages globally, followed by India (55\%), Saudi Arabia (50\%), Afghanistan (40\%), Iran (30\%), Egypt and Turkey (20\%) [5]. The prevalence of consanguineous unions differs amongst countries due to socio-demographic factors, such as geography (urban-rural residential community, isolated area and population), religion, education, socio-economic status, familial pattern towards early marriages or consanguinity between parents [4, 6-12]. Although the incidence of consanguineous unions somehow decreased with urbanization, modernization and smaller/nuclear families, however, it is still in practice [13].

Pakistan, a multi-cultural country with diverse caste systems, has been showing consistently the highest prevalence of consanguinity $[14,15]$. Consanguineous marriages are encouraged in the country due to multiple reasons, e.g. to strengthen interfamily ties between close family members, a preference to the same caste and status, fear of incompatibility or difficulty in finding the right partner outside the family, security of being familiar with spouse and in-laws prior to marriage, restriction for socialization with opposite gender, and financial constraints especially for dowry [16]. However, various socio-cultural and health related implications have been identified for consanguineous 
couples $\left.{ }^{5}\right]$. Owing to shared alleles, consanguinity may lead to genetic disorders $[17,18]$, poor pregnancy outcomes or multiple reproductive and fertility consequences, having adverse effects on mothers, their children, family and society as a whole $[5,13]$. A strong association of consanguineous marriages has been reported with increased rates of abortion, still births, pregnancy terminations, low birth weights, increased mortality and congenital malformations $[13,17,19-23]$. Furthermore, a low preference for contraception, extended child bearing age and higher fertility has also been observed in such unions [8]. Although consanguineous marriages are also linked with poor pregnancy outcomes [22] and higher reproductive risks in Pakistan, nonetheless the are also associated with increased fertility rates and larger family size $[24,25]$.

Consanguineous unions have remained under continuous investigation of social scientists, medical researchers, biologists and physicians. However, it received less attention in mainstream demographic research. Although multiple studies are available regarding effects of consanguineous marriages on either reproductive health or fertility behaviors [22, 24, 25], nevertheless, there is a need to examine and explain the trends of consanguineous marriages and their association with women's reproductive health and fertility behavior in Pakistan. This research is an attempt to investigate the differentials in reproductive health and fertility behaviors over a period of almost three decades (1990-2018).

\section{Methods}

\section{Study design and data source}

This research performed a secondary data analysis, using all four waves of Pakistan Demographic and Health Surveys (PDHSs), carried out during 1990-91 (wave 1) [26], 2006-07 (wave 2) [27], 2012-13 (wave 3) [28], and 2017-18 (wave 4) [29]. These PDHSs are characterized as nationally representative and large-scale cross-sectional household surveys, conducted under the international series of MEASURE Demographic and Health Survey (DHS) Program and funded by the United States Agency for International Development (USAID). These surveys were carried out by the National Institute of Population Studies (NIPS) with technical assistance of ICF International and Pakistan Bureau of Statistics. A series of PDHSs is the largest household and publicly available dataset, with information on women's reproductive health, fertility behavior, marital status and other socio-demographic variables. Each PDHS applied a random two-stage cluster sampling design, wherein firstly rural and urban sampling units were chosen, followed by the selection of eligible households with ever-married women (aged 15-49 years) [26-29].

Within each wave of PDHS, varied numbers of field teams collected data, each comprised of one male and three female interviewers, field editor and supervisor. All teams were closely monitored by quality-controllers, provincial/regional field coordinators, as well as the NIPS and ICF core team. Simultaneously, data editing, processing and double data entry of completed questionnaires was also completed. Each wave of PDHSs used various questionnaires at household, community, women and men levels for data collection. This research used the standard female questionnaire for data analysis, administered to women (aged 15-49 years), using face-to-face method [26-29], and including questions about consanguinity, women's reproductive health and fertility behaviors. The response rate was recorded between $93 \%$ to $94.5 \%$ for each wave of PDHS [26-29].

This research limited analysis to the women of reproductive age (15-49 years), who had given birth in the previous years preceding each of the four PDHS waves during 1990 to 2018 . Therefore, the sample size used for this study was $4,061,5,677,7,446$, and 6,711, for 1990-91, 2006-07, 2012-13, and 2017-18, respectively.

\section{Variables}

Page $3 / 24$ 


\section{Outcome variable:}

The outcome variable for this research is marital status of respondents, i.e. non-consanguineous marriage vs. consanguineous marriage. Further, types of consanguineous marriages were divided into three categories, including married to paternal first cousins, married to maternal first cousins, and married to relatives other than first paternal or maternal cousins.

\section{Reproductive health and fertility behavior:}

Various variables related to women's reproductive health and fertility behavior were selected based on literature $[1,5,8,13,19,21,22,25]$. These included age at first birth (<20 years, 20-34 years, 35-49 years), gravidity (1-2, 3-5, 6 and above), parity (1-2, 3-4, 5 children and above), number of living children (none, 1-2, 3-4, 5 and above), ever terminated pregnancy (yes/no), antenatal care (ANC) visits during last pregnancy (less than 4 visits, 4 visits and above), skilled birth attendants (SBA) at delivery during the last pregnancy (yes/no), ideal family size (1-2, 3-4, 5 and above), fertility intention/desired family size (wants more children, wants no more, i.e. undecided, sterilized, declared infecund), and current use of contraception (yes/no).

\section{Sociodemographic characteristics and co-variates:}

The sociodemographic characteristics included geographical classification (urban, rural), regions/provinces (Islamabad, Sindh, Punjab, Khyber Pakhtunkhwa, FATA, Baluchistan, Gilgit Baltistan), respondent's age in years (1524, 25-34, 35 years and above), education status (uneducated, primary, secondary, higher) as well as employment status of respondents and their husbands (unemployed, employed), and wealth quintile (richest, richer, middle, poorer, poorest). Other co-variates included exposure to mass media to access information (yes/no) and respondents' healthcare decision-making autonomy (yes/no).

\section{Statistical analysis}

Data analysis was conducted using SPSS version 21. Initially, sample weights were calculated and descriptive statistics were presented in the form of frequencies and percentages. For bivariate analyses, cross-tabulation and chi-square tests were applied. Afterwards, bivariable and multivariable logistic regression analyses were performed to measure the association of consanguineous marriages with sociodemographic characteristics, as well as women's reproductive health and fertility behaviors. During regression analysis, odds ratios (OR) and adjusted odds ratios (AOR) were calculated with $95 \%$ confidence interval (Cl). A p-value $\leq 0.05$ was considered statistically significant.

\section{Results}

\section{Sample characteristics}

Table 1 highlights respondents' socio-demographic characteristics and other co-variates for the four PDHS waves from 1990 to 2018. The majority of women were of 25-34 years of age, uneducated (but with a lower trend over time: $79.2 \%, 64.6 \%, 55.8 \%$, and $47.9 \%)$, and resided in rural areas $(70.9 \%, 69.8 \%, 59.9 \%$, and $66.5 \%)$. About three quarter or even more of the women were unemployed. Contrary to respondents, most of their husbands acquired secondary level of education and almost all of them were employed. Although, findings revealed that about $60-70 \%$ of women had exposure to mass media, about half of the participants had no autonomy in healthcare decision making. 


\section{Trend of consanguineous marriages}

Table 2 shows the proportion of consanguineous marriages amongst women of reproductive age from 1990 to 2018. Results indicate that about two thirds of women were married to their cousins, more frequently with paternal first cousin than maternal. Findings revealed an overall stable proportion of consanguinity prevalence during last three decades. However, even a slightly upward trend of consanguineous marriages was witnessed from $63.0 \%$ in 1990-91 to 67.9\% in 2007-08, followed by a gradual downwards trend. Similarly, the pattern of marriages with paternal and maternal first cousins decreased during the period from 1990 to 2013, nonetheless, slightly increased in 2017-18.

\section{Reproductive health and fertility behavior related characteristics}

Table 2 demonstrates the characteristics related to women's reproductive health and fertility behavior during 1990 to 2018. Results indicated that the majority of respondents gave their first birth at an age below 20 years and had multi-gravida pregnancies between 3-5 times (44.5\%, 43.3\%, 43.4\%, and $44.8 \%)$. Parity of 5 children and more decreased over time $(41.2 \%, 35.7 \%, 31.1 \%$, and $26.5 \%)$. The proportion of deliveries conducted by unskilled birth attendants during the last pregnancy constantly decreased from $81.5 \%$ in $1990-91$ to $28.0 \%$ in $2017-18$. Findings also revealed the gradual improvement in women's reproductive healthcare seeking behaviors, particularly in availing at least 4 ANC visits and deliveries conducted by SBAs during 1990 to 2018 . Furthermore, regarding women's fertility behavior, the analysis indicated that most of the women (68.8\%) reported an ideal family size of 5 children and above in 1990, which decreased over time to 3-4 children in 2017-18 (51.8\%). Although about half of the respondents showed no more desire for children or fertility intention in all four waves, there was a high - but overall decreasing - rate of not using contraception $(88.3 \%, 70.6 \%, 62.7 \%$, and $63.9 \%)$.

\section{Bivariate association of consanguinity with various factors}

The association of consanguineous marriages with various factors - including sociodemographic characteristics, and reproductive health and fertility behaviors - amongst respondents of reproductive age in each of the four PDHS waves is presented in Table 3. Findings demonstrate the significant relationship of consanguinity with regions/provinces, urban/rural geographical classification, respondents' education, wealth quintile, mass media exposure and healthcare decision-making autonomy in all waves. Respondents' age, employment status and their husbands' educational status was also found statistically significant in most of the PDHS waves. Furthermore, results highlight the significant relationship of consanguinity with respondents' age at first birth, ANC visits, deliveries by SBAs, ideal family size, fertility intention and current use of contraception in the majority of PDHS waves. In a few PDHS waves, a strong association of consanguineous unions was also observed with the number of living children, gravidity, and pregnancy termination.

\section{Bivariable and multivariable logistic regression}

Table 4 depicts the results of the bivariable logistic regression analysis of consanguinity with respondents' sociodemographic characteristics, reproductive health and fertility behaviors. Almost all sociodemographic variables in the four PDHS waves were significantly associated with consanguinity - at least one category per item. However, husband's employment status was only significant for 2017-18. Furthermore, gravidity and parity, and number of children showed nearly no significant associations.

When interpreting the results of the multivariable logistic regression analysis (Table 5), one needs to keep in mind that not all variables and categories have been assessed in all four waves. However, the results highlight that 
respondent's age was not significantly associated with consanguinity. The region and geographical classification were significant predictors of consanguinity, except for 2017-18. The impact of education was contrary between women and their husband: Women with higher education had a lower likelihood for consanguineous marriages, whereas men with higher education were more likely to marry their relatives. The strength of the association for both variables reduced over time. Employment status both for women and their husband showed inconclusive results the only significant association was found for employed omen showing a higher likelihood of consanguinity in 2012-13 (AOR=1.23, 95\% Cl: 1.08-1.39, p<0.01).

In 1990-91, the wealth index was not significantly associated with consanguinity, but for all other waves a higher wealth quintile was linked with lower likelihood of consanguineous marriages. For example, in 2012-13 (AOR=0.53, 95\% Cl: 0.41-0.69, p<0.01) and 2017-18 (AOR=0.47, 95\% Cl: 0.35-0.62, p<0.01) the likelihood was halved in the richest wealth quintile compared to the poorest one. There was no impact of mass media exposure and respondent's healthcare decision-making autonomy, except for 2012-13, where women having decision-making autonomy were less likely to be married with relatives (AOR=0.83, 95\% Cl: $0.74-0.92, p<0.01)$.

As already shown in the bivariable logistic regression models, respondent's age at fist birth, gravidity and parity, and number of children showed almost no or only in some years or categories significant associations. Nevertheless, there is a trend younger age at first birth and lower gravidity is linked with consanguineous marriages. In 1990-91 and 2006-07, a lower number of children was associated with a higher likelihood for consanguineous marriages, ever having terminated a pregnancy was only significantly associated with a higher likelihood for consanguinity in 2012-13 (AOR=1.29, 95\% Cl: 1.15-1.44, p<0.01). Visits of ANC and deliveries by SBAs were also no significant predictors, except for single exceptions. However, an ideal family size of less than five children was almost entirely significantly associated with not marrying a relative. The use of contraceptive was not significantly associated with consanguineous marriages.

\section{Discussion}

With the advanced research and expansion of knowledge in public health and social sciences, the topic of consanguineous unions has received higher importance. From the beginning of mankind, consanguinity or close-kin marriages was socially and culturally deeply rooted. Although it is presumed that the rates of consanguineous marriages decline with modernization and literacy, this is not transferable to all countries [30]. Presently, consanguinity is widely popular and respected in many communities, particularly in Muslims [2, 3]. Pakistan ranks amongst those countries, where the highest prevalence of consanguinity is still in vogue $[3,22,25]$. This article examined the trends of consanguineous marriages over the period of approximately three decades, from 1990 to 2018, and their association with women's reproductive health and fertility behavior in Pakistan. It is an effort to bridge the gap in existing literature, documenting the relevance of consanguinity with reproductive health and fertility behavior amongst women, who had given births in five years preceding each of the four PDHS waves.

The results showed a varied trend of consanguineous marriages in Pakistan, which increased from 63.0\% in $1990-$ 91 to $67.9 \%$ in 2006-07, however, declined to $66.2 \%$ during $2012-13$ and $63.6 \%$ in 2018 . This highlights the fact that popularity of consanguineous unions is not declining in the country, because of social, cultural, religious and economic advantages, which out-weigh the disadvantages in view of the population [31]. In particular, consanguinity promotes family stability, inheritance and spouse compatibility, nonetheless lessens hidden financial risks $[6,7,16$, 32]. These results are similar to other studies, carried out in many subpopulations within Pakistan [33], such as northern Punjab [34, 35], southern Khyber Pakhtunkhwa [36], Balochistan [37], Kashmir [38], and also in other Arab 
countries [1, 39], Yemen [40], Qatar [41] and Algeria [42]. Contrary, these results are not consistent to some of the research, where a decreasing trend in consanguineous unions was reported over time $[43,44]$.

This research also reiterated that consanguinity is associated with sociodemographic characteristics, as results demonstrated that consanguineous marriages are more prevalent amongst uneducated women, living in rural areas, and with poorer wealth status. These findings are comparable to other studies, where less educated women get married with cousins at younger age, particularly in poor traditional rural areas [10,45-48]. This highlights the need to educate and empower young girls, enabling them to make better decisions in life to ensure their well-being.

Previous empirical results found a strong association of consanguineous unions with women's reproductive health and fertility behaviors. Findings demonstrated that those women who married to their cousins were more likely to give first birth at younger age (between 20-34 years). Although not entirely significant in our analysis, we can also confirm this result. Our findings correspond to the previous studies, showing that consanguinity is associated with higher fertility rates and larger family sizes, which affects the health of both mothers and children $[5,8,13,22,24$, 25]. Thus, there is a need to educate communities about linkages of consanguinity with poor reproductive health, adverse impact on fertility outcomes and overall family health. This research emphasizes to educate families regarding implications of consanguinity and associated health risks, through increasing public awareness, providing informational material, promoting health education and enhancing capacities of primary healthcare and outreach workers to counsel communities effectively on health and social issues related to consanguineous marriages. It is pertinent to actively engage all key stakeholders at public and private sector to promote healthy mothers, children and communities.

\section{Limitations}

Since this research analyzed the four waves of PDHS from 1990 to 2018, few variables were not uniform and found missing, particularly in PDHS 1990-91 and 2006-07, such as regions/provinces, mass media exposure, respondent's healthcare decision-making autonomy and pregnancy termination. Due to the cross-sectional design, we are not able to draw any causal conclusions. When interpreting the results, one need to consider that some of the variables might be predictors of consanguineous marriages (such as low education), whereas others are effects (such as visits of ANC and deliveries by SBAs) or both (such as ideal family size).

\section{Conclusion}

This research concludes that consanguineous marriages are predominant in Pakistan, particularly in the context of the large power structure and patriarchal society. Findings revealed that consanguinity is associated with sociodemographic characteristics and women's reproductive health and fertility behaviors in Pakistan. The high prevalence of consanguineous marriages and their implications on women's health is essential to be considered in health policies. There is also a dire need to actively engage public health and reproductive health professionals to promote health and wellbeing of the female population. Appropriate counselling, health educational and promotional programmes related to consanguinity should be designed and launched at community level to raise awareness. Though there are multiple socio-cultural and economic benefits of consanguinity perceived by women in Pakistan, improvements in health literacy and behavior change will endorse attitudinal change in society.

\section{Abbreviations}

ANC Antenatal care 
AOR Adjusted odds ratio

Cl Confidence interval

OR Odds ratio

PDHS Pakistan Demographic and Health Survey

SBA Skilled birth attendant

SPSS Statistical Package for the Social Sciences

\section{Declarations}

\section{Ethical Approval and Consent to Participate}

This study is based on a secondary data analysis. Therefore, not ethical approval is required. All participants provided written informed consent before data collection.

\section{Consent for Publication}

Not applicable.

\section{Availability of Data and Materials}

Data is available from the Demographic and Health Survey program: https://dhsprogram.com/

\section{Competing Interest}

The authors declare that no competing interest exist. FF serves on the Editorial Board of BMC Women's Health as Associate Editor.

\section{Funding}

This research received no supporting funds from any funding agency in the public, commercial, or not-for-profit sector.

\section{Authors Contributions}

The study was conceptualized by SI and RZ. SI analysed the data, RZ and MZZ supervised data analysis. SI drafted the manuscript; RZ, FF and MZZ revised it critically for important intellectual content. All authors reviewed the final version of the manuscript.

\section{Acknowledgements}

We acknowledge support from the German Research Foundation (DFG) and the Open Access Publication Fund of Charité - Universitätsmedizin Berlin.

\section{References}


1. Tadmouri GO, Nair P, Obeid T, Al Ali TM, Al Khaja N, Hamamy HA. Consanguinity and reproductive health among Arabs. Reprod Health. 2009;6:17.

2. Bittles AH. The global prevalence of consanguinity. 2015. http://www.consang.net/index.php/Global_prevalence. Accessed January 31, 2020.

3. Riaz HF, Mannan S, Malik S. Consanguinity and its socio-biological parameters in Rahim Yar Khan District, Southern Punjab, Pakistan. J Health Popul Nutr. 2016;35:14.

4. Bittles $\mathrm{AH}$, Black ML. Evolution in health and medicine Sackler colloquium: Consanguinity, human evolution, and complex diseases. Proc Natl Acad Sc USA. 2010;107(Suppl 1):1779-86.

5. Olubunmia O, Nevesb K, Badreldeenc A, Konjea JC. A review of the reproductive consequences of consanguinity. Eur J Obstet Gynecol Reprod Biol. 2019;232:87-96.

6. Teebi AS, Teebi SA, Porter CJ, Cuticchia AJ. Arab Genetic Disease Database (AGDDB): A population-specific clinical and mutation database. Hum Mutat. 2002;19(6):615-21.

7. Anwar WA, Khyatti M, Hemminki K. Consanguinity and genetic diseases in North Africa and immigrants to Europe. Eur J Public Health. 2014;24(Suppl. 1):57-63.

8. Bittles AH, Grant J, Sullivan SG, Hussain R. Does inbreeding lead to decreased human fertility? Ann Hum Biol. 2002;29(2):111-30.

9. Hamamy H, Jamhawi L, Al-Darawsheh J, Ajlouni K. Consanguineous marriages in Jordan: why is the rate changing with time? Clin Genet. 2005;67(6):511-6.

10. Bener A, Abdulrazzaq YM, Al-Gazali LI, Micallef R, Al-Khayat Al, Gaber T. Consanguinity and associated sociodemographic factors in the United. Arab Emirates Hum Hered. 1996;46(5):256-64.

11. Sureender S, Prabakaran B, Khan AG. Mate selection and its impact on female marriage age, pregnancy wastages, and first child survival in Tamil Nadu, India. Soc Biol. 1998;45(3-4):289-301.

12. Jaber L, Bailey-Wilson JE, Haj-Yehia M, Hernandez J, Shohat M. Consanguineous matings in an Israeli-Arab community. Arch Pediatr Adolesc Med. 1994;148(4):412-5.

13. Metgud CS, Naik VA, Mallapur MD. Consanguinity and pregnancy outcome among rural pregnant women of Belgaum district. Nat J Commun Med. 2012;3(4):681-4.

14. Agha N. Kinship in rural Pakistan: Consanguineous marriages and their implications for women. Women's Studies International Forum. 2016;54:1-10.

15. Jones GW. Changing marriage patterns in Asia. Asia Research Institute Working Paper Series No 131. Asia Research Institute and Department of Sociology. National University of Singapore; 2010.

16. Qidwai W, Syed IA, Khan FM. Prevalence and perceptions about consanguineous marriages among patients presenting to family physicians, in 2001 at a Teaching Hospital in Karachi, Pakistan. Asia Pacific Family Medicine. 2003;2(1):27-31.

17. Devi ACP, Sudarsanam D. Role of Consanguinity in Mental Retardation. Asian J Exp Biol Sci. 2011;2:162-4.

18. McKusick V. Human Genetics. 2nd ed. New Delhi: Prentice Hall of India; 1972.

19. Zakar R, Zakar MZ, Aqil N. Adverse birth outcomes associated with consanguineous marriage in Pakistan. Int J Gynecology Obstet. 2014;127(2):211-2.

20. Hasnain SF, Hashmi SK. Consanguinity among the risk factors for underweight in children under five: A study from rural Sindh. Journal of Ayub Medical College Abbottabad. 2009;21(3):111-6.

21. Ullah MA, Husseni AM, Mahmood SU. Consanguineous marriages and their detrimental outcomes in Pakistan: An urgent need for appropriate measures. International Journal of Community Medicine Public Health. 
2018;5(1):1-3.

22. Omer S, Farooq S, Jabeen S. Effects of cousin marriages on adverse pregnancy outcomes among women in Pakistan: A secondary analysis of data from the Pakistan Demographic and Health Survey 2012-13. Pakistan Journal of Women's Studies. 2016;23(1):65-76.

23. RoyChoudhary AK. Incidence of in-breeding in different States of India. Demography India. 1976;5:108-15.

24. Shami SA, Schmitt LH, Bittles AH. Consanguinity, spousal age at marriage and fertility in seven Pakistani Punjab cities. Ann Hum Biol. 1990;17(2):97-105.

25. Manzoor R, Imran W, Maken AM, Syed TH. Consanguineous marriages: Effects on pregnancy outcomes in Pakistan. Journal of Development Policy Research Practice. 2018;2:1.

26. National Institute of Population Studies (NIPS). Pakistan Demographic and Health Survey (PDHS) 1990-91. Maryland: Macro International Inc.; 1991.

27. National Institute of Population Studies (NIPS). Pakistan Demographic and Health Survey (PDHS) 2006-07. Maryland: Macro International Inc.; 2007.

28. National Institute of Population Studies (NIPS). Pakistan Demographic and Health Survey (PDHS) 2012-13. Maryland: Macro International Inc.; 2013.

29. National Institute of Population Studies (NIPS). Pakistan Demographic and Health Survey (PDHS) 2017-18. Maryland: Macro International Inc.; 2018.

30. Baykara-Krumme H. Consanguineous marriage in Turkish families in Turkey and in Western Europe. Int Migration Rev. 2018;50(3):568-98.

31. Jaber L, Halpern GJ, Shohat M. The impact of consanguinity worldwide. Community Genet. 1998;1:12-7.

32. Bittles AH. Endogamy, consanguinity and community genetics. J Genet. 2002;81(3):91-8.

33. Hussain R, Bittles $\mathrm{AH}$. The prevalence and demographic characteristics of consanguineous marriages in Pakistan. J Biosoc Sci. 1998;30(2):261-75.

34. Shami SA, Grant JC, Bittles AH. Consanguineous marriages within social/occupational class boundaries in Pakistan. J Biosoc Sci. 1994;26(1):91-6.

35. Hina S, Malik S. Pattern of consanguinity and inbreeding coefficient in Sargodha district, Punjab, Pakistan. J Biosoc Sci. 2015;47(6):803-11.

36. Wahab A, Ahmad M. Biosocial perspectives of consanguineous marriages in rural and urban Swat, Pakistan. J Biosoc Sci. 1996;28(3):305-13.

37. Maian A, Mushtaq R. Consanguinity in population of Quetta (Pakistan): A preliminary study. Geography. 1994;5:49-53.

38. Jabeen N, Malik S. Consanguinity and its socio-demographic differentials in district Bhimber, Azad Jammu Kashmir, Pakistan. J Health Popul Nutr. 2014;32(2):301-13.

39. Al-Gazali LI, Bener A, Abdulrazzaq YM, Micallef R, Al-Khayat Al, Gaber T. Consanguineous marriages in the United Arab Emirates. J Biosoc Sci. 1997;29(4):491-7.

40. Jurdi R, Saxena PC. The prevalence and correlates of consanguineous marriages in Yemen: Similarities and contrasts with other Arab countries. J Biosoc Sci. 2003;35(1):1-13.

41. Bener A, Alali KA. Consanguineous marriage in a newly developed country: The Qatari population. J Biosoc Sci. 2006;38(2):239-46.

42. Zaoui S, Biemont C. Frequency of consanguineous unions in the Tlemcen area (West Algeria). Sante. 2002;12(3):289-95. 
43. Nath A, Patil C, Naik VA. Prevalence of consanguineous marriages in a rural community and its effect on pregnancy outcome. Indian Journal of Community Medicine. 2004;29(1):41-3.

44. Godhi SA, Metgud CS, Mallapur MD. Prevalence of consanguineous marriage and its effect on pregnancy outcome in a rural area. Journal of Scientific Society. 2009;36:93-5.

45. Bittles $\mathrm{AH}$. The role and significance of consanguinity as a demographic variable. Popul Dev Rev. 1994;20(3):561-84.

46. Shah NM. Women's socioeconomic characteristics and marital patterns in a rapidly developing muslim society, Kuwait. Journal of Comparative Family Studies. 2004;35(2):163-83.

47. Weinreb AA. Characteristics of women in consanguineous marriages in Egypt, 1988-2000. European Journal of Population. 2008;24(2):185-210.

48. Koc I. Prevalence and socio-demographic correlates of consanguineous marriages in Turkey. J Biosoc Sci. 2008;40(1):137-48.

\section{Tables}


Table 1

Sociodemographic characteristics and co-variates of respondents

\begin{tabular}{|c|c|c|c|c|c|c|c|c|}
\hline \multirow[t]{3}{*}{ Characteristics } & \multicolumn{2}{|c|}{ PDHS (1990-91) } & \multicolumn{2}{|c|}{ PDHS (2006-07) } & \multicolumn{2}{|c|}{ PDHS (2012-13) } & \multicolumn{2}{|c|}{ PDHS (2017-18) } \\
\hline & \multicolumn{2}{|c|}{$n=4,061$} & \multicolumn{2}{|c|}{$n=5,677$} & \multicolumn{2}{|c|}{$n=7,446$} & \multicolumn{2}{|c|}{$n=6,711$} \\
\hline & $f$ & $\%$ & f & $\%$ & $f$ & $\%$ & f & $\%$ \\
\hline \multicolumn{9}{|c|}{ Sociodemographic characteristics } \\
\hline \multicolumn{9}{|l|}{ Regions/Provinces } \\
\hline Punjab & 2,441 & 60.1 & 3,182 & 56.1 & 4,180 & 56.1 & 3,453 & 51.5 \\
\hline Sindh & 894 & 22 & 1,404 & 24.7 & 1,714 & 23 & 1,571 & 23.4 \\
\hline Baluchistan & 159 & 3.9 & 264 & 4.6 & 348 & 15 & 377 & 5.6 \\
\hline Khyber Pakhtunkhwa a & 567 & 14 & 827 & 14.6 & 1,117 & 4.7 & 1,101 & 16.4 \\
\hline Gilgit Baltistan* & - & - & - & - & 56 & 0.7 & - & - \\
\hline Islamabad* & - & - & - & - & 31 & 0.4 & 54 & 0.8 \\
\hline FATA* & - & - & - & - & - & - & 156 & 2.3 \\
\hline \multicolumn{9}{|c|}{ Geographical classification } \\
\hline Urban & 1,184 & 29.1 & 1,714 & 30.2 & 2,244 & 30.1 & 2,248 & 33.5 \\
\hline Rural & 2,877 & 70.9 & 3,962 & 69.8 & 5,202 & 69.9 & 4,463 & 66.5 \\
\hline
\end{tabular}

\section{Respondents' age}

\begin{tabular}{llllllllll}
$15-24$ years & 983 & 24.2 & 1,334 & 23.5 & 1,748 & 23.5 & 1,545 & 23 \\
\hline $25-34$ years & 2,061 & 50.7 & 2,952 & 52.0 & 4,038 & 54.2 & 3,725 & 55.5 \\
\hline 35 years and above & 1,017 & 25 & 1,390 & 24.5 & 1,659 & 22.3 & 1,440 & 21.5
\end{tabular}

a Khyber Pakhtunkhwa was formerly known as North-West Frontier Province (NWFP), as previously reported in PDHS 1990-91 and 2006-07.

${ }^{b}$ Mass media exposure refers to the frequency of reading a newspaper or watching TV or listening to radio

* Missing information indicates the non-availability of data within the respective PDHS wave. 


\begin{tabular}{|c|c|c|c|c|c|c|c|c|}
\hline \multirow[t]{3}{*}{ Characteristics } & \multicolumn{2}{|c|}{ PDHS (1990-91) } & \multicolumn{2}{|c|}{ PDHS (2006-07) } & \multicolumn{2}{|c|}{ PDHS (2012-13) } & \multicolumn{2}{|c|}{ PDHS (2017-18) } \\
\hline & \multicolumn{2}{|c|}{$n=4,061$} & \multicolumn{2}{|c|}{$n=5,677$} & \multicolumn{2}{|c|}{$n=7,446$} & \multicolumn{2}{|c|}{$n=6,711$} \\
\hline & $f$ & $\%$ & $f$ & $\%$ & $f$ & $\%$ & $f$ & $\%$ \\
\hline \multicolumn{9}{|c|}{ Respondents' education status } \\
\hline Uneducated & 3,214 & 79.2 & 3,668 & 64.6 & 4,155 & 55.8 & 3,212 & 47.9 \\
\hline Primary & 373 & 9.2 & 854 & 15.0 & 1,230 & 16.5 & 1,097 & 16.3 \\
\hline Secondary & 427 & 10.5 & 813 & 14.3 & 1,380 & 18.5 & 1,492 & 22.2 \\
\hline Higher & 47 & 1.2 & 341 & 6.0 & 682 & 9.2 & 911 & 13.6 \\
\hline \multicolumn{9}{|c|}{ Husbands' education status } \\
\hline Uneducated & 1,946 & 48.2 & 2,007 & 35.4 & 2,451 & 33 & 1,889 & 28.7 \\
\hline Primary & 698 & 17.3 & 935 & 16.5 & 1,211 & 16.3 & 1,085 & 16.5 \\
\hline Secondary & 1,213 & 30 & 1,904 & 33.5 & 2,547 & 34.3 & 2,316 & 35.2 \\
\hline Higher & 181 & 4.5 & 812 & 14.3 & 1,216 & 16.4 & 1,293 & 19.6 \\
\hline \multicolumn{9}{|c|}{ Respondents' employment status } \\
\hline Unemployed & 3,389 & 83.5 & 4,026 & 71.0 & 5,378 & 72.2 & 5,528 & 82.4 \\
\hline Employed & 669 & 16.5 & 1,647 & 29.0 & 2,068 & 27.8 & 1,180 & 17.6 \\
\hline \multicolumn{9}{|c|}{ Husbands' employment status } \\
\hline Unemployed & 77 & 2 & 174 & 3.1 & 123 & 1.7 & 173 & 2.6 \\
\hline Employed & 3,844 & 98 & 5,501 & 96.9 & 7,322 & 98.3 & 6,415 & 97.4 \\
\hline \multicolumn{9}{|l|}{ Wealth quintile } \\
\hline Richest & 1,085 & 26.7 & 1,029 & 18.1 & 1,272 & 17.1 & 1,248 & 18.6 \\
\hline Richer & 923 & 22.7 & 1,066 & 18.8 & 1,469 & 19.7 & 1,349 & 20.1 \\
\hline Middle & 755 & 18.6 & 1,099 & 19.4 & 1,464 & 19.7 & 1,371 & 20.4 \\
\hline Poorer & 689 & 17 & 1,194 & 21.0 & 1,544 & 20.7 & 1,299 & 19.4 \\
\hline Poorest & 609 & 15 & 1,289 & 22.7 & 1,698 & 22.8 & 1,444 & 21.5 \\
\hline \multicolumn{9}{|l|}{ Covariates } \\
\hline \multicolumn{9}{|c|}{ Mass media exposure *b } \\
\hline Yes & 1,636 & 59.5 & - & - & 5,241 & 70.6 & 4,254 & 63.4 \\
\hline
\end{tabular}

a Khyber Pakhtunkhwa was formerly known as North-West Frontier Province (NWFP), as previously reported in PDHS 1990-91 and 2006-07.

${ }^{b}$ Mass media exposure refers to the frequency of reading a newspaper or watching TV or listening to radio

* Missing information indicates the non-availability of data within the respective PDHS wave. 


\begin{tabular}{|c|c|c|c|c|c|c|c|c|}
\hline \multirow[t]{3}{*}{ Characteristics } & \multicolumn{2}{|c|}{ PDHS (1990-91) } & \multicolumn{2}{|c|}{ PDHS (2006-07) } & \multicolumn{2}{|c|}{ PDHS (2012-13) } & \multicolumn{2}{|c|}{ PDHS (2017-18) } \\
\hline & \multicolumn{2}{|c|}{$n=4,061$} & \multicolumn{2}{|c|}{$n=5,677$} & \multicolumn{2}{|c|}{$n=7,446$} & \multicolumn{2}{|c|}{$n=6,711$} \\
\hline & f & $\%$ & f & $\%$ & f & $\%$ & $f$ & $\%$ \\
\hline No & 2,404 & 40.5 & - & - & 2,184 & 29.4 & 2,454 & 36.6 \\
\hline \multicolumn{9}{|c|}{ Respondents' healthcare decision-making autonomy* } \\
\hline Yes & - & - & - & - & 3,511 & 47.9 & 3,054 & 46.2 \\
\hline No & - & - & - & - & 3,826 & 52.1 & 3,550 & 53.8 \\
\hline \multicolumn{9}{|c|}{$\begin{array}{l}\text { a Khyber Pakhtunkhwa was formerly known as North-West Frontier Province (NWFP), as previously reported in } \\
\text { PDHS } 1990-91 \text { and } 2006-07 \text {. }\end{array}$} \\
\hline \multicolumn{9}{|c|}{${ }^{\mathrm{b}}$ Mass media exposure refers to the frequency of reading a newspaper or watching TV or listening to radio } \\
\hline
\end{tabular}


Table 2

Measures to describe consanguinity, reproductive health and fertility behavior

\begin{tabular}{|c|c|c|c|c|}
\hline \multirow[t]{3}{*}{ Characteristics } & $\begin{array}{l}\text { PDHS } \\
(1990-91)\end{array}$ & $\begin{array}{l}\text { PDHS } \\
(2006-07)\end{array}$ & $\begin{array}{l}\text { PDHS } \\
(2012-13)\end{array}$ & $\begin{array}{l}\text { PDHS } \\
(2017-18)\end{array}$ \\
\hline & $n=4,061$ & $n=5,677$ & $n=7,446$ & $n=6,711$ \\
\hline & $\%$ & $\%$ & $\%$ & $\%$ \\
\hline
\end{tabular}

\section{Consanguinity}

\section{Marital status}

Non-consanguineous marriages

Consanguineous marriages

Type of consanguineous marriages

Married to paternal first cousins

Married to maternal first cousins

Married to relatives other than first paternal/maternal cousins

\begin{tabular}{rrrrrrrr}
1,500 & 37 & 1,819 & 32.1 & 2,519 & 33.8 & 2,440 & 36.4 \\
\hline 2,550 & 63 & 3,855 & 67.9 & 4,926 & 66.2 & 4,270 & 63.6
\end{tabular}

$\begin{array}{llllllll}1,223 & 47.9 & 1,814 & 47.1 & 2,061 & 41.9 & 1,882 & 44.1\end{array}$

$\begin{array}{llllllll}856 & 33.6 & 1,198 & 31.1 & 1,558 & 31.7 & 1,433 & 33.6\end{array}$

$\begin{array}{llllllll}471 & 18.5 & 842 & 21.8 & 1,300 & 26.4 & 953 & 22.3\end{array}$

Reproductive health and fertility behavior

\section{Age at first birth}

\begin{tabular}{|c|c|c|c|c|c|c|c|c|}
\hline$<20$ years & 2,390 & 58.8 & 3,072 & 54.1 & 3,685 & 49.5 & 3,076 & 45.8 \\
\hline $20-34$ years & 1,648 & 40.6 & 2,588 & 45.6 & 3,733 & 50.1 & 3,593 & 53.5 \\
\hline $35-49$ years & 23 & 0.6 & 17 & 0.3 & 28 & 0.4 & 42 & 0.6 \\
\hline \multicolumn{9}{|l|}{ Gravidity } \\
\hline $1-2$ & 1,306 & 32.2 & 2,071 & 36.5 & 2,980 & 40 & 2,829 & 42.2 \\
\hline $3-5$ & 1,808 & 44.5 & 2,456 & 43.3 & 3,233 & 43.4 & 3,009 & 44.8 \\
\hline 6 and above & 947 & 23.3 & 1,150 & 20.3 & 1,233 & 16.6 & 873 & 13 \\
\hline \multicolumn{9}{|l|}{ Parity } \\
\hline 1-2 children & 1,245 & 30.7 & 2,000 & 35.2 & 2,885 & 38.7 & 2,749 & 41 \\
\hline $3-4$ children & 1,142 & 28.1 & 1,648 & 29 & 2,249 & 30.2 & 2,183 & 32.5 \\
\hline 5 children and above & 1,674 & 41.2 & 2,029 & 35.7 & 2,312 & 31.1 & 1,780 & 26.5 \\
\hline \multicolumn{9}{|c|}{ Number of living children } \\
\hline None & 71 & 1.7 & 100 & 1.8 & 80 & 1.1 & 83 & 1.2 \\
\hline $1-2$ & 1,360 & 33.5 & 2,138 & 37.7 & 3,149 & 42.3 & 2,944 & 43.9 \\
\hline $3-4$ & 1,294 & 31.9 & 1,737 & 30.6 & 2,306 & 31.0 & 2,222 & 33.1 \\
\hline 5 and above & 1,336 & 32.9 & 1,702 & 30.0 & 1,912 & 25.7 & 1,463 & 21.8 \\
\hline
\end{tabular}

* Missing information indicates the non-availability of data within the respective PDHS wave. 


\begin{tabular}{|c|c|c|c|c|c|c|c|c|}
\hline \multirow[t]{3}{*}{ Characteristics } & \multirow{2}{*}{\multicolumn{2}{|c|}{$\begin{array}{l}\text { PDHS } \\
(1990-91) \\
n=4,061\end{array}$}} & \multirow{2}{*}{\multicolumn{2}{|c|}{$\begin{array}{l}\text { PDHS } \\
(2006-07) \\
n=5,677\end{array}$}} & \multirow{2}{*}{\multicolumn{2}{|c|}{$\begin{array}{l}\text { PDHS } \\
(2012-13) \\
n=7,446\end{array}$}} & \multirow{2}{*}{\multicolumn{2}{|c|}{$\begin{array}{l}\text { PDHS } \\
\text { (2017-18) } \\
n=6,711\end{array}$}} \\
\hline & & & & & & & & \\
\hline & $f$ & $\%$ & $f$ & $\%$ & $f$ & $\%$ & $f$ & $\%$ \\
\hline \multicolumn{9}{|c|}{ Ever terminated pregnancy* } \\
\hline Yes & - & - & 1,352 & 23.8 & 2,512 & 33.7 & 2,166 & 32.3 \\
\hline No & - & - & 4,320 & 76.2 & 4,935 & 66.3 & 4,545 & 67.7 \\
\hline \multicolumn{9}{|l|}{ Visits for antenatal care } \\
\hline Less than 4 visits & 3410 & 85.8 & 3987 & 71.2 & 4713 & 63.4 & 2,414 & 41.1 \\
\hline At least 4 visits or more & 564 & 14.2 & 1611 & 28.8 & 2723 & 36.6 & 3,452 & 58.9 \\
\hline \multicolumn{9}{|c|}{ Deliveries by skilled birth attendants } \\
\hline Yes & 743 & 18.5 & 2365 & 41.9 & 4112 & 55.2 & 4,833 & 72 \\
\hline No & 3285 & 81.5 & 3280 & 58.1 & 3312 & 44.5 & 1,879 & 28 \\
\hline \multicolumn{9}{|l|}{ Ideal family size } \\
\hline $1-2$ & 219 & 5.4 & 735 & 12.9 & 1,055 & 14.2 & 1,174 & 17.5 \\
\hline $3-4$ & 1,045 & 25.8 & 3,032 & 53.4 & 4,200 & 56.4 & 3,479 & 51.8 \\
\hline 5 and above & 2,791 & 68.8 & 1,910 & 33.6 & 2,191 & 29.4 & 2,059 & 30.7 \\
\hline \multicolumn{9}{|c|}{ Desire for more children / Fertility intention } \\
\hline Wants more children & 1,748 & 43.7 & 2,647 & 46.7 & 3,592 & 49 & 3,115 & 47.2 \\
\hline Wants no more & 2,254 & 56.3 & 3,023 & 53.3 & 3,745 & 51 & 3,480 & 52.8 \\
\hline \multicolumn{9}{|c|}{ Current use of contraception } \\
\hline Yes & 475 & 11.7 & 1,670 & 29.4 & 2,774 & 37.3 & 2,421 & 36.1 \\
\hline No & 3,586 & 88.3 & 4,007 & 70.6 & 4,672 & 62.7 & 4,290 & 63.9 \\
\hline
\end{tabular}


Table 3

Relationship of consanguinity with sociodemographic characteristics, reproductive health and fertility behavior CharacteristicsPDHS (1990-91)

$n=4,061$

PDHS (2006-07)

PDHS (2012-13)

$n=7,446$

PDHS (2017-18)

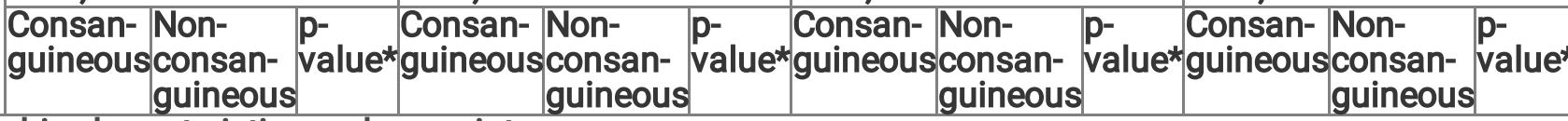
Sociodemographic characteristics and co-variates

Regions/Provinces

Punjab 165.6

Sindh

65.6

34.4

$<0.0168$.

\begin{tabular}{|l|l|}
\hline 68.4 & 31.6 \\
\hline 73.0 & 27.0 \\
\hline 72.3 & 27.7 \\
\hline 56.1 & 43.9 \\
\hline- & - \\
\hline- & - \\
\hline- & - \\
\hline
\end{tabular}

$<0.0165 .6$

\begin{tabular}{l|l}
71.4 & 28.6 \\
\hline 69.7 & 30.3
\end{tabular}

Baluchistan 70.3

38.4

Khyber

51.9

48.1

69.7

30.3

\begin{tabular}{ll}
\hline 60.3 & 39.7
\end{tabular}

Gilgit Baltistan-

$-$

Islamabad

FATA

$-$

$-$

Geographical classification

\begin{tabular}{|c|c|c|c|c|c|c|c|c|c|c|c|c|}
\hline Urban & 53.1 & 46.9 & \multirow{2}{*}{\multicolumn{2}{|c|}{\begin{tabular}{r|r}
$<0.01$ & $\frac{60.0}{71.4}$
\end{tabular}}} & 40.0 & \multirow[t]{2}{*}{$<0.01$} & 54.8 & 45.2 & \multirow[t]{2}{*}{0.00} & 58.6 & 41.4 & \multirow[t]{2}{*}{$<0.01$} \\
\hline Rural & 67.0 & 33.0 & & & 28.6 & & 71.1 & 28.9 & & 66.2 & 33.8 & \\
\hline \multicolumn{13}{|l|}{$\begin{array}{l}\text { Respondents' } \\
\text { age }\end{array}$} \\
\hline $15-24$ years & 67.3 & 32.7 & $<0.01$ & 70.1 & 29.9 & 0.12 & 70.4 & 29.6 & $<0.0^{\circ}$ & 68.8 & 31.2 & 0.1 \\
\hline $25-34$ years & 62.4 & 37.6 & & 66.9 & 33.1 & & 64.8 & 35.2 & & 62.1 & 37.9 & \\
\hline 35 years and & 59.8 & 40.2 & & 68.1 & 31.9 & & 65.0 & 35.0 & & 62.0 & 38.0 & \\
\hline
\end{tabular}

above

Respondents' education status

\begin{tabular}{|l|l|l|}
\hline Uneducated & 65.0 & 35.0 \\
\hline Primary & 64.8 & 35.2 \\
\hline Secondary & 48.2 & 51.8 \\
\hline Higher & 41.3 & 58.7 \\
\hline
\end{tabular}

Husbands' education status

\begin{tabular}{l|l|l}
\hline Uneducated & 61.1 & 38.9
\end{tabular}

\begin{tabular}{|l|l|l}
\hline Primary & 68.9 & 31.1 \\
\hline Secondary & 63.5 & 36.5 \\
\hline
\end{tabular}

\begin{tabular}{l|l|l}
\hline Secondary & 63.5 & 36.5 \\
\hline
\end{tabular}

\begin{tabular}{l|l|l} 
Higher & 54.7 & 45.3
\end{tabular}

Respondents' employment status

\begin{tabular}{|l|l|l|}
\hline Unemployed & 62.2 & 37.8
\end{tabular}

\begin{tabular}{lll}
\hline Employed & 66.8 & 33.2
\end{tabular}

\begin{tabular}{l|l|l|}
$<0.01$ & 70.5 & 29.5 \\
\hline 67.5 & 32.5 \\
\hline 62.3 & 37.7 \\
\hline 55.0 & 45.0 \\
\hline
\end{tabular}

\begin{tabular}{|l|l|}
\hline 51.8 & 48.2 \\
\hline 58.1 & 41.9 \\
\hline
\end{tabular}

$\begin{array}{ll}51.8 .1 & 41.9\end{array}$

\begin{tabular}{l|l|l|l|}
\hline$<0.0160$ & 40 & $<0.01$
\end{tabular}

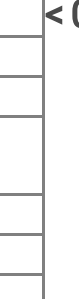

\begin{tabular}{l|l}
\hline 73.8 & 26.2 \\
\hline 64.7 & 35.3
\end{tabular}

\begin{tabular}{l|l}
\hline 3.8 & 35.3 \\
\hline 64.7 & 38.3
\end{tabular}

\begin{tabular}{l|l}
\hline 61.7 & 38.3
\end{tabular}

Husbands' employment status

\begin{tabular}{|c|c|c|c|c|c|c|c|c|c|c|c|c|}
\hline Unemployed & 66.7 & 33.3 & \multirow[t]{2}{*}{0.47} & 68.4 & 31.6 & \multirow[t]{2}{*}{0.89} & 70.7 & 29.3 & \multirow[t]{2}{*}{0.28} & 71.5 & 28.5 & \multirow[t]{2}{*}{0.03} \\
\hline Employed & 62.7 & 37.3 & & 67.9 & 32.1 & & 66.1 & 33.9 & & 63.7 & 36.3 & \\
\hline \multicolumn{13}{|c|}{ Mass media exposure } \\
\hline Yes & 59.0 & 41.0 & \multirow[t]{2}{*}{$<0.01$} & - & - & - & 64.0 & 36 & \multirow{2}{*}{\multicolumn{2}{|c|}{$<0.01 \frac{61.6}{67.1}$}} & 38.4 & \multirow[t]{2}{*}{$<0.01$} \\
\hline No & 66.0 & 34.0 & & - & - & & 71.4 & 28.6 & & & 32.9 & \\
\hline \multicolumn{13}{|c|}{ Wealth quintile } \\
\hline Richest & 59.9 & 40.1 & \multirow[t]{5}{*}{$<0.01$} & 61.3 & 38.7 & $<0.01$ & 54.7 & 45.3 & \multirow[t]{5}{*}{$<0.01$} & 51.4 & 48.6 & \multirow[t]{5}{*}{$<0.01$} \\
\hline Richer & 60.1 & 39.9 & & 62.7 & 37.3 & & 56.6 & 43.4 & & 58.8 & 41.2 & \\
\hline Middle & 61.1 & 38.9 & & 66.2 & 33.8 & & 66.1 & 33.9 & & 65.9 & 34.1 & \\
\hline Poorer & 69.8 & 30.2 & & 69.8 & 30.2 & & 71.5 & 28.5 & & 65.4 & 34.6 & \\
\hline Poorest & 67.1 & 32.9 & & 77.3 & 22.7 & & 78.3 & 21.7 & & 74.9 & 25.1 & \\
\hline \multicolumn{9}{|c|}{ Respondent's healthcare decision-making autonomy } & & & & \multirow{3}{*}{0.04} \\
\hline Yes & - & - & - & - & - & - & 63.2 & 36.8 & \multirow[t]{2}{*}{$<0.0^{\circ}$} & 162.6 & 37.4 & \\
\hline No & - & - & & - & - & & 69.2 & 30.8 & & 65.1 & 34.9 & \\
\hline
\end{tabular}

Reproductive health and fertility behaviors

Respondent's age at first birth

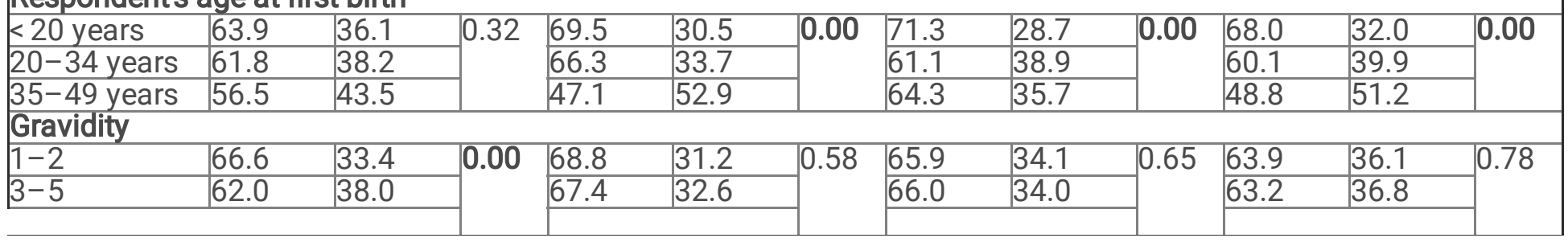




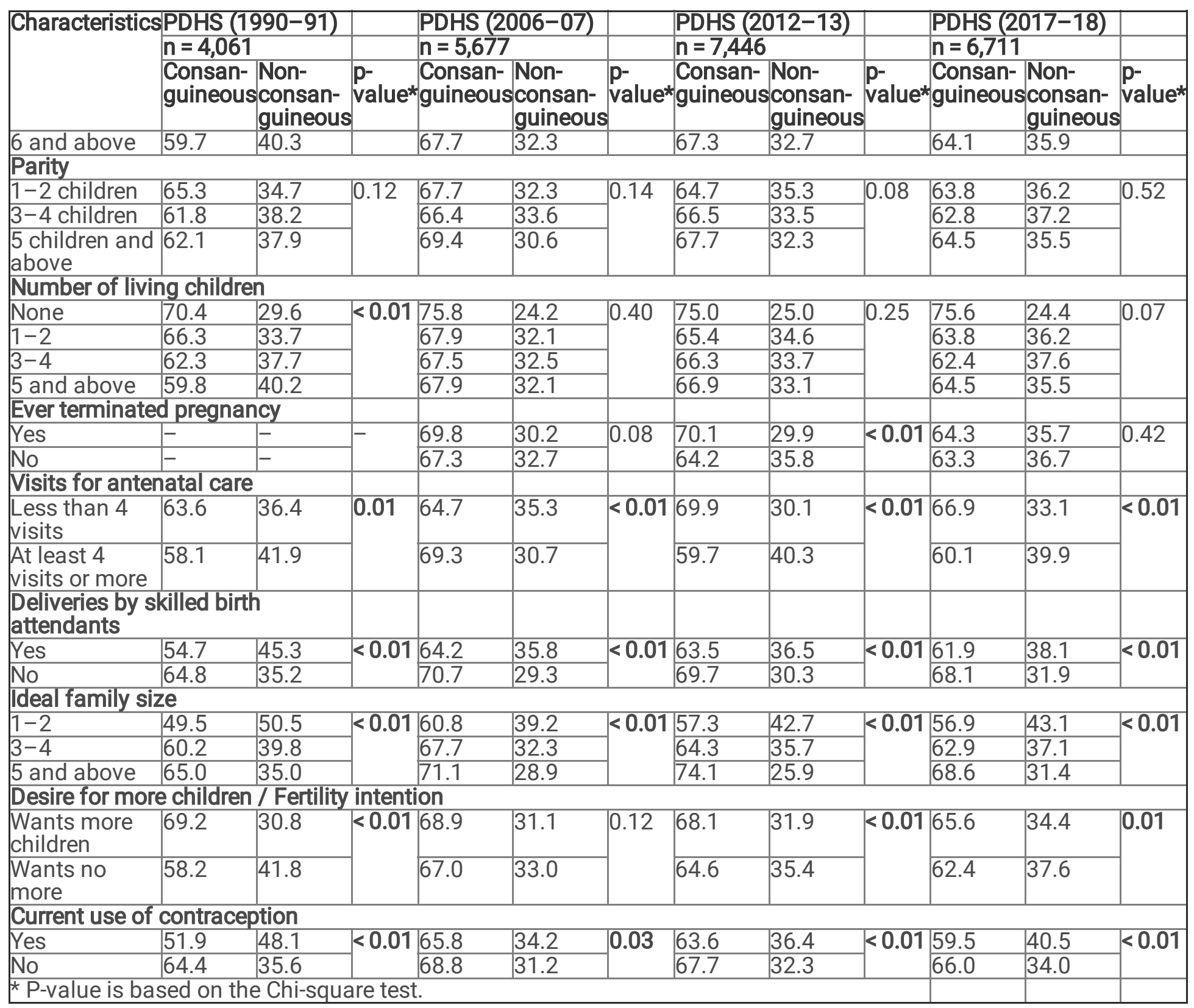


Table 4

Bivariable logistic regression of Consanguinity with sociodemographic characteristics, reproductive health and

\begin{tabular}{|c|c|c|c|c|c|c|c|c|c|}
\hline \multirow[t]{2}{*}{ Characteristics } & \multicolumn{3}{|c|}{$\begin{array}{l}\text { PDHS (1990-91) } \\
n=4.061\end{array}$} & \multicolumn{2}{|c|}{ PDHS (2006-07) } & \multicolumn{2}{|c|}{ PDHS (2012-13) } & \multicolumn{2}{|c|}{ PDHS (2017-18) } \\
\hline & OR & $95 \% \mathrm{Cl}$ & p-value & OR $95 \% \mathrm{Cl}$ & $\begin{array}{l}\mathrm{p}- \\
\text { value }\end{array}$ & OR $95 \% \mathrm{Cl}$ & $\begin{array}{l}\mathrm{p}- \\
\text { value }\end{array}$ & OR $95 \% \mathrm{Cl}$ & $\begin{array}{l}\mathrm{p}- \\
\text { value }\end{array}$ \\
\hline \multicolumn{10}{|c|}{ Sociodemographic characteristics and co-variates } \\
\hline Regions/Provinces & & & & & & & & & \\
\hline Khyber Pakhtunkhwa & 1 & & & 1 & & 1 & & 1 & \\
\hline Punjab & 1.76 & $1.47-2.12$ & $<0.01$ & \begin{tabular}{c|c}
1.70 & $1.45-$ \\
1.99
\end{tabular} & $<0.01$ & $\begin{array}{c}1.25 \mid \begin{array}{l}1.09- \\
1.43\end{array} \\
\end{array}$ & $<0.01$ & \begin{tabular}{l|l}
0.93 & $0.81-$ \\
1.07
\end{tabular} & 0.30 \\
\hline Sindh & 1.48 & $1.20-1.84$ & $<0.01$ & $\begin{array}{l}2.111 .76- \\
2.53\end{array}$ & $<0.01$ & $\begin{array}{c}1.641 .39- \\
1.92\end{array}$ & $<0.01$ & $\begin{array}{c}1.741 .47- \\
2.05\end{array}$ & $<0.01$ \\
\hline Baluchistan & 2.19 & $1.50-3.19$ & $<0.01$ & $\begin{array}{l}2.051 .51- \\
2.78\end{array}$ & $<0.01$ & $1.51 \mid \begin{array}{l}1.17- \\
1.95\end{array}$ & $<0.01$ & 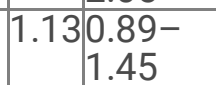 & 0.31 \\
\hline Gilgit Baltistan & - & - & - & - & - & $\begin{array}{c}0.70 \\
0.41- \\
1.21\end{array}$ & 0.20 & - & - \\
\hline Islamabad & - & - & - & - & - & \begin{tabular}{c|l}
0.88 & $0.43-$ \\
1.82
\end{tabular} & 0.75 & \begin{tabular}{l|l|l|}
$0.76 .44-$ \\
1.32
\end{tabular} & 0.34 \\
\hline FATA & - & - & - & - & - & & & $0.790 \begin{array}{l}0.56- \\
1.12\end{array}$ & 0.19 \\
\hline \multicolumn{10}{|c|}{ Geographical classification } \\
\hline Rural & 1 & & & 1 & & 1 & & 1 & \\
\hline Urban & 0.55 & $0.48-0.64$ & $<0.01$ & \begin{tabular}{c|c}
0.60 & $0.53-$ \\
0.68
\end{tabular} & $<0.01$ & \begin{tabular}{c|l}
0.49 & $\begin{array}{l}0.45- \\
0.55\end{array}$
\end{tabular} & $<0.01$ & \begin{tabular}{c|c}
0.72 & $\begin{array}{l}0.65- \\
0.80\end{array}$
\end{tabular} & $<0.01$ \\
\hline \multicolumn{10}{|l|}{ Respondents' age } \\
\hline $15-24$ years & 1 & & & 1 & & 1 & & 1 & \\
\hline $25-34$ years & 0.80 & $0.68-0.94$ & $<0.01$ & \begin{tabular}{c|c}
0.86 & $0.75-$ \\
0.99
\end{tabular} & 0.04 & \begin{tabular}{c|c}
0.77 & $0.68-$ \\
0.87
\end{tabular} & $<0.01$ & $0.75 \mid \begin{array}{l}0.65- \\
0.84\end{array}$ & $<0.01$ \\
\hline 35 years and above & 0.72 & $0.60-0.86$ & $<0.01$ & $\begin{array}{l}0.910 .77- \\
1.07\end{array}$ & 0.27 & $\begin{array}{c}0.780 .67- \\
0.90\end{array}$ & $<0.01$ & $\begin{array}{c}0.740 .63- \\
0.86\end{array}$ & $<0.01$ \\
\hline \multicolumn{10}{|c|}{ Respondents' education status } \\
\hline Uneducated & 1 & & & 1 & & 1 & & 1 & \\
\hline Primary & 0.99 & $0.79-1.24$ & 0.93 & \begin{tabular}{l|l}
0.87 & $0.74-$ \\
1.02
\end{tabular} & 0.08 & \begin{tabular}{c|c}
0.81 & $0.70-$ \\
& 0.92
\end{tabular} & $<0.01$ & $0.84 \mid \begin{array}{l}0.73- \\
0.97\end{array}$ & 0.02 \\
\hline Secondary & 0.50 & $0.41-0.61$ & $<0.01$ & \begin{tabular}{c|l}
0.69 & $0.59-$ \\
& 0.81
\end{tabular} & $<0.01$ & $\begin{array}{c}0.550 .49- \\
0.63\end{array}$ & $<0.01$ & \begin{tabular}{c|c}
0.66 & $0.58-$ \\
0.75
\end{tabular} & $<0.01$ \\
\hline Higher & 0.37 & $0.20-0.67$ & $<0.01$ & \begin{tabular}{c|c}
0.51 & $0.41-$ \\
& 0.64
\end{tabular} & $<0.01$ & \begin{tabular}{c|c}
0.38 & $0.33-$ \\
& 0.45
\end{tabular} & $<0.01$ & \begin{tabular}{c|l}
0.43 & $\begin{array}{l}0.37- \\
0.50\end{array}$
\end{tabular} & $<0.01$ \\
\hline \multicolumn{10}{|c|}{ Husbands' education status } \\
\hline Uneducated & 1 & & & 1 & & 1 & & 1 & \\
\hline Primary & 1.41 & $1.17-1.69$ & $<0.01$ & \begin{tabular}{l|l}
1.02 & $0.86-$ \\
1.21
\end{tabular} & 0.79 & \begin{tabular}{c|}
1.11 \\
$0.95-$ \\
1.28
\end{tabular} & 0.17 & \begin{tabular}{l|l}
1.13 & $0.96-$ \\
1.33
\end{tabular} & 0.12 \\
\hline Secondary & 1.11 & $0.96-1.29$ & 0.16 & \begin{tabular}{c|c}
0.94 & $0.82-$ \\
1.07
\end{tabular} & 0.33 & \begin{tabular}{c|c}
0.91 & $0.81-$ \\
1.02
\end{tabular} & 0.10 & $0.83\left[\begin{array}{l}0.73- \\
0.94\end{array}\right.$ & 0.01 \\
\hline Higher & 0.77 & $0.56-1.05$ & 0.09 & \begin{tabular}{l|l}
0.89 & $0.75-$ \\
1.06
\end{tabular} & 0.21 & \begin{tabular}{c|c}
0.77 & $0.66-$ \\
& 0.89
\end{tabular} & $<0.01$ & \begin{tabular}{c|c}
0.66 & $0.57-$ \\
0.77
\end{tabular} & $<0.01$ \\
\hline \multicolumn{10}{|c|}{ Respondents' employment status } \\
\hline Unemployed & 1 & & & 1 & & 1 & & 1 & \\
\hline Employed & 1.22 & $1.02-1.45$ & 0.02 & \begin{tabular}{c|c}
1.33 & $1.17-$ \\
1.51
\end{tabular} & $<0.01$ & \begin{tabular}{c|c}
1.67 & $1.49-$ \\
1.87
\end{tabular} & $<0.01$ & \begin{tabular}{l|l}
1.09 & $0.95-$ \\
1.24
\end{tabular} & 0.19 \\
\hline \multicolumn{10}{|c|}{ Husbands' employment status } \\
\hline Unemployed & 1 & & & 1 & & 1 & & 1 & \\
\hline Employed & 0.84 & $0.52-1.35$ & 0.47 & $\begin{array}{ll}0.97 & 0.71- \\
1.35\end{array}$ & 0.89 & \begin{tabular}{c|c}
0.79 & $0.54-$ \\
1.18
\end{tabular} & 0.25 & \begin{tabular}{c|c}
0.70 & $0.50-$ \\
0.98
\end{tabular} & 0.03 \\
\hline \multicolumn{10}{|l|}{ Mass media exposure } \\
\hline No & 1 & & & & & 1 & & 1 & \\
\hline Yes & 0.74 & $0.65-0.85$ & $<0.01$ & - & - & $\begin{array}{c}0.71 \begin{array}{l}0.64- \\
0.79\end{array} \\
\end{array}$ & $<0.01$ & $\begin{array}{c}0.78 \\
0.71- \\
0.87\end{array}$ & $<0.01$ \\
\hline \multicolumn{10}{|c|}{$\begin{array}{l}\text { Respondents' healthcare decision-making } \\
\text { autonomy }\end{array}$} \\
\hline No & & & & & & 1 & & 1 & \\
\hline
\end{tabular}




\begin{tabular}{|c|c|c|c|c|c|c|c|c|c|}
\hline \multirow[t]{3}{*}{ Characteristics } & \multirow{2}{*}{\multicolumn{3}{|c|}{\begin{tabular}{|l} 
PDHS (1990-91) \\
$n=4,061$
\end{tabular}}} & \multirow{2}{*}{\multicolumn{2}{|c|}{$\begin{array}{l}\text { PDHS (2006-07) } \\
n=5,677\end{array}$}} & \multirow{2}{*}{\multicolumn{2}{|c|}{$\begin{array}{l}\text { PDHS (2012-13) } \\
n=7,446\end{array}$}} & \multirow{2}{*}{\multicolumn{2}{|c|}{$\begin{array}{l}\text { PDHS (2017-18) } \\
n=6,711\end{array}$}} \\
\hline & & & & & & & & & \\
\hline & OR & $95 \% \mathrm{Cl}$ & p-value & OR $95 \% \mathrm{Cl}$ & $\begin{array}{l}\text { p- } \\
\text { value }\end{array}$ & OR $95 \% \mathrm{Cl}$ & $\begin{array}{l}p^{-}- \\
\text {value }\end{array}$ & OR $95 \% \mathrm{Cl}$ & $\begin{array}{l}p^{-} \\
\text {value }\end{array}$ \\
\hline Yes & - & - & - & - & - & \begin{tabular}{c|c}
0.76 & $0.69-$ \\
0.84
\end{tabular} & $<0.01$ & \begin{tabular}{c|l}
0.89 & $0.83-$ \\
0.96
\end{tabular} & $<0.01$ \\
\hline \multicolumn{10}{|l|}{ Wealth quintile } \\
\hline Poorest & 1 & & & 1 & & 1 & & 1 & \\
\hline Poorer & 1.13 & $0.89-1.43$ & 0.31 & $\begin{array}{c}0.680 .57- \\
0.81\end{array}$ & $<0.01$ & $\begin{array}{c}0.690 .59- \\
0.82\end{array}$ & $<0.01$ & $0.630 .54-$ & $<0.01$ \\
\hline Middle & 0.77 & $0.61-0.96$ & 0.02 & $\begin{array}{c}0.570 .48- \\
0.69\end{array}$ & $<0.01$ & $0.540 .46-$ & $<0.01$ & $0.650 .55-$ & $<0.01$ \\
\hline Richer & 0.74 & $0.60-0.92$ & $<0.01$ & \begin{tabular}{l|l}
0.49 & $0.41-$ \\
0.59
\end{tabular} & $<0.01$ & $\begin{array}{c}0.360 .31- \\
0.42\end{array}$ & $<0.01$ & $\begin{array}{l}0.470 .41- \\
0.56\end{array}$ & $<0.01$ \\
\hline Richest & 0.73 & $0.59-0.90$ & $<0.01$ & 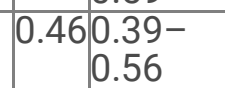 & $<0.01$ & $\begin{array}{c}0.330 .28- \\
0.39\end{array}$ & $<0.01$ & $\begin{array}{c}0.35\left[\begin{array}{c}0.30- \\
0.41\end{array}\right. \\
0\end{array}$ & $<0.01$ \\
\hline \multirow{2}{*}{\multicolumn{10}{|c|}{$\begin{array}{l}\text { Reproductive health and fertility behaviors } \\
\text { Respondents' age at first birth }\end{array}$}} \\
\hline & birth & & & & & & & & \\
\hline$<20$ years & 1 & & & 1 & & 1 & & 1 & \\
\hline $20-34$ years & 0.91 & $0.80-1.04$ & 0.17 & $\begin{array}{c}0.86 \\
0.77- \\
0.96\end{array}$ & 0.01 & $\begin{array}{c}0.630 .57- \\
0.70\end{array}$ & $<0.01$ & $\begin{array}{c}0.71 \mid \begin{array}{c}0.64- \\
0.78\end{array} \\
0.7\end{array}$ & $<0.01$ \\
\hline $35-49$ years & 0.69 & $0.30-1.58$ & 0.38 & $\begin{array}{c}0.37 \\
0.14- \\
0.97\end{array}$ & 0.04 & $\begin{array}{c}0.750 .34- \\
1.65\end{array}$ & 0.48 & $\begin{array}{c}0.45 \mid \begin{array}{l}0.24- \\
0.83\end{array} \\
\end{array}$ & 0.01 \\
\hline \multicolumn{10}{|l|}{ Gravidity } \\
\hline 6 and above & 1 & & & 1 & & 1 & & 1 & \\
\hline & 1.10 & $0.94-1.29$ & 0.23 & $\begin{array}{c}0.980 .85- \\
1.14\end{array}$ & 0.86 & $\begin{array}{c}0.940 .81- \\
1.07\end{array}$ & 0.37 & $\begin{array}{c}0.96 \\
\\
1.12\end{array}$ & 0.61 \\
\hline $1-2$ & 1.35 & $1.13-1.60$ & $<0.01$ & $\begin{array}{c}1.050 .90- \\
1.23\end{array}$ & 0.51 & $\begin{array}{l}0.940 .82- \\
1.08\end{array}$ & 0.41 & $\begin{array}{c}0.99 \\
0.84- \\
1.16\end{array}$ & 0.91 \\
\hline \multicolumn{10}{|l|}{ Parity } \\
\hline 5 children and above & 1 & & & 1 & & 1 & & 1 & \\
\hline 3-4 children & 0.98 & $0.84-1.15$ & 0.88 & $\begin{array}{c}0.870 .76- \\
1.00\end{array}$ & 0.05 & $\begin{array}{l}0.950 .84- \\
1.07\end{array}$ & 0.38 & $0.930 .81-$ & 0.26 \\
\hline $1-2$ children & 1.15 & $0.98-1.34$ & 0.07 & $\begin{array}{c}0.920 .81- \\
1.05\end{array}$ & 0.23 & $\begin{array}{c}0.880 .78- \\
0.98\end{array}$ & 0.02 & $\begin{array}{c}0.970 .86- \\
1.10\end{array}$ & 0.65 \\
\hline \multicolumn{10}{|l|}{ Number of living children } \\
\hline 5 chil & 1 & & & 1 & & 1 & & 1 & \\
\hline $3-4$ children & 1.11 & $0.94-1.29$ & 0.19 & {$\left[\begin{array}{ll}0.98 \\
1.13 \\
1.13-\end{array}\right.$} & 0.79 & $0.97 \begin{array}{l}0.85- \\
1.11\end{array}$ & 0.69 & $0.91\left[\begin{array}{l}0.79- \\
1.05\end{array}\right.$ & 0.20 \\
\hline $1-2$ children & 1.32 & $1.13-1.54$ & $<0.01$ & $1.000 .87-$ & 0.98 & $0.930 .83-$ & 0.28 & $0.970 .85-$ & 0.68 \\
\hline None & 1.61 & $0.95-2.71$ & 0.07 & $\begin{array}{c}1.450 .91- \\
2.32\end{array}$ & 0.12 & $\begin{array}{c}1.440 .86- \\
2.41\end{array}$ & 0.16 & $\begin{array}{c}1.701 .02- \\
2.84\end{array}$ & 0.04 \\
\hline \multicolumn{10}{|l|}{ Ever terminated pregnancy } \\
\hline No & & & & 1 & & 1 & & 1 & \\
\hline Yes & - & - & - & $\begin{array}{c}2.312 .06- \\
2.59\end{array}$ & $<0.01$ & $\begin{array}{l}1.31 \\
1.18- \\
1.45\end{array}$ & $<0.01$ & $\left.1.10\right|_{1.19} ^{1.02-}$ & 0.01 \\
\hline \multicolumn{10}{|l|}{ Visits for antenatal care } \\
\hline Less than 4 visits & 1 & & & 1 & & 1 & & 1 & \\
\hline At least 4 visits or more & 0.79 & $0.66-0.95$ & 0.01 & $\begin{array}{c}1.831 .65- \\
2.03\end{array}$ & $<0.01$ & $\begin{array}{r}0.640 .58- \\
0.70\end{array}$ & $<0.01$ & $\begin{array}{c}0.740 .67- \\
0.83\end{array}$ & $<0.01$ \\
\hline \multicolumn{10}{|c|}{ Deliveries by skilled birth attendants } \\
\hline No & 1 & & & 1 & & 1 & & 1 & \\
\hline Yes & 0.66 & $0.56-0.77$ & $<0.01$ & \begin{tabular}{c|c}
1.79 & $1.64-$ \\
1.95
\end{tabular} & $<0.01$ & $\begin{array}{c}0.750 .68- \\
0.83\end{array}$ & $<0.01$ & $\begin{array}{c}0.760 .68- \\
0.85\end{array}$ & $<0.01$ \\
\hline \multicolumn{10}{|l|}{ Ideal family size } \\
\hline 5 children or above & 1 & & & 1 & & 1 & & 1 & \\
\hline $3-4$ children & 0.81 & $0.70-0.94$ & 0.01 & $\begin{array}{c}0.63 \\
0.53- \\
0.75\end{array}$ & $<0.01$ & \begin{tabular}{c|c}
0.62 & $0.56-$ \\
0.70
\end{tabular} & $<0.01$ & $\begin{array}{c}0.78 \\
0.69- \\
0.87\end{array}$ & $<0.01$ \\
\hline $1-2$ children & 0.53 & $0.40-0.69$ & $<0.01$ & $\begin{array}{c}0.850 .75- \\
0.96\end{array}$ & 0.01 & $\begin{array}{c}0.460 .40- \\
0.54\end{array}$ & $<0.01$ & $\begin{array}{c}0.600 .52- \\
0.70\end{array}$ & $<0.01$ \\
\hline \multicolumn{10}{|c|}{ Desire for more children / Fertility intention } \\
\hline Wants more children & 1 & & & 1 & & 1 & & 1 & \\
\hline
\end{tabular}




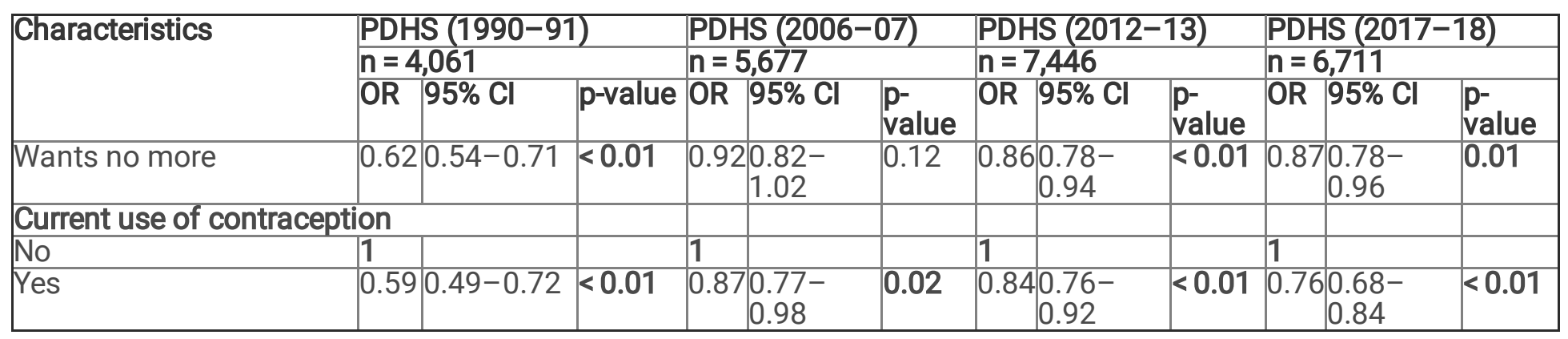


Table 5

Bivariable logistic regression of Consanguinity with sociodemographic characteristics, reproductive health and

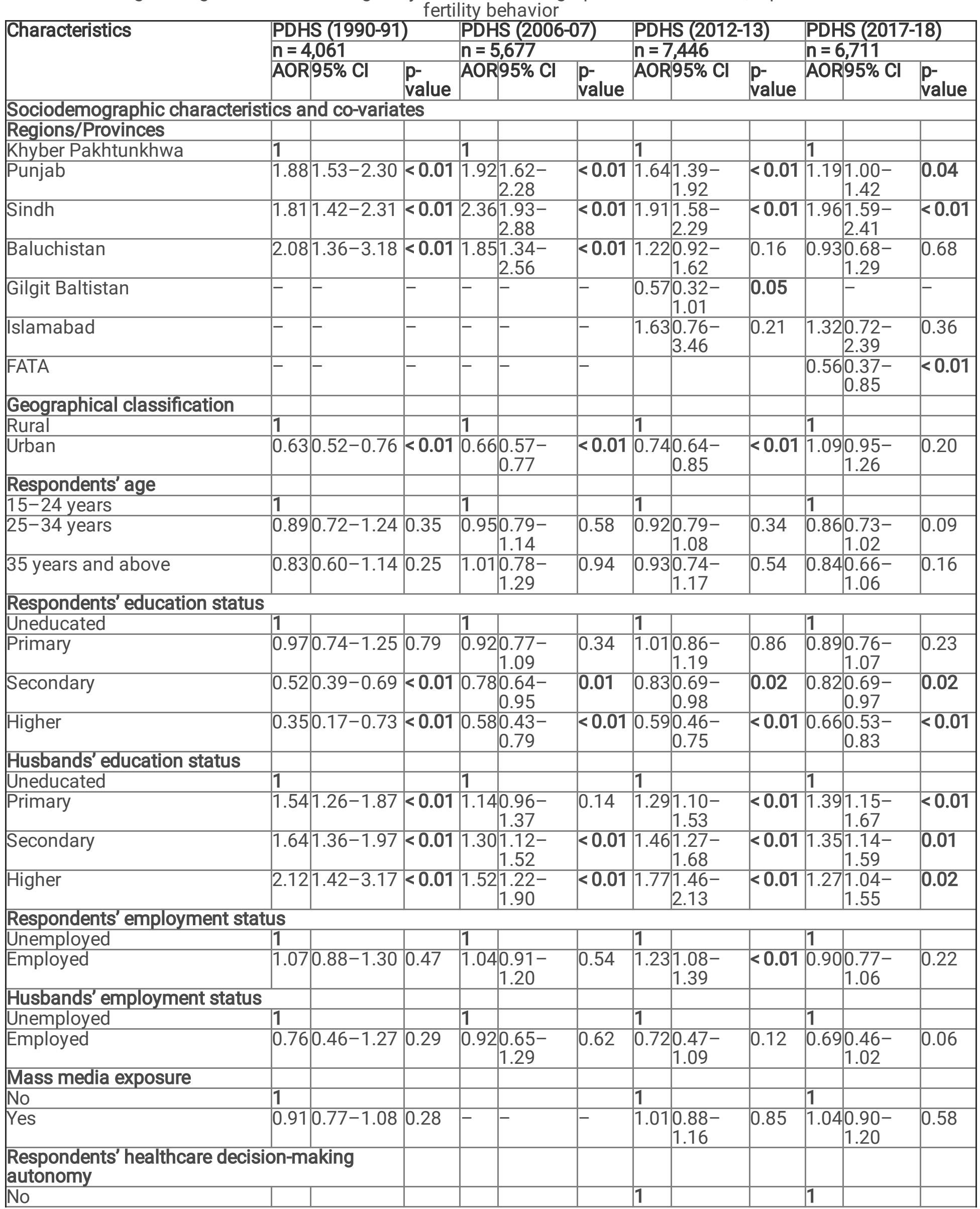




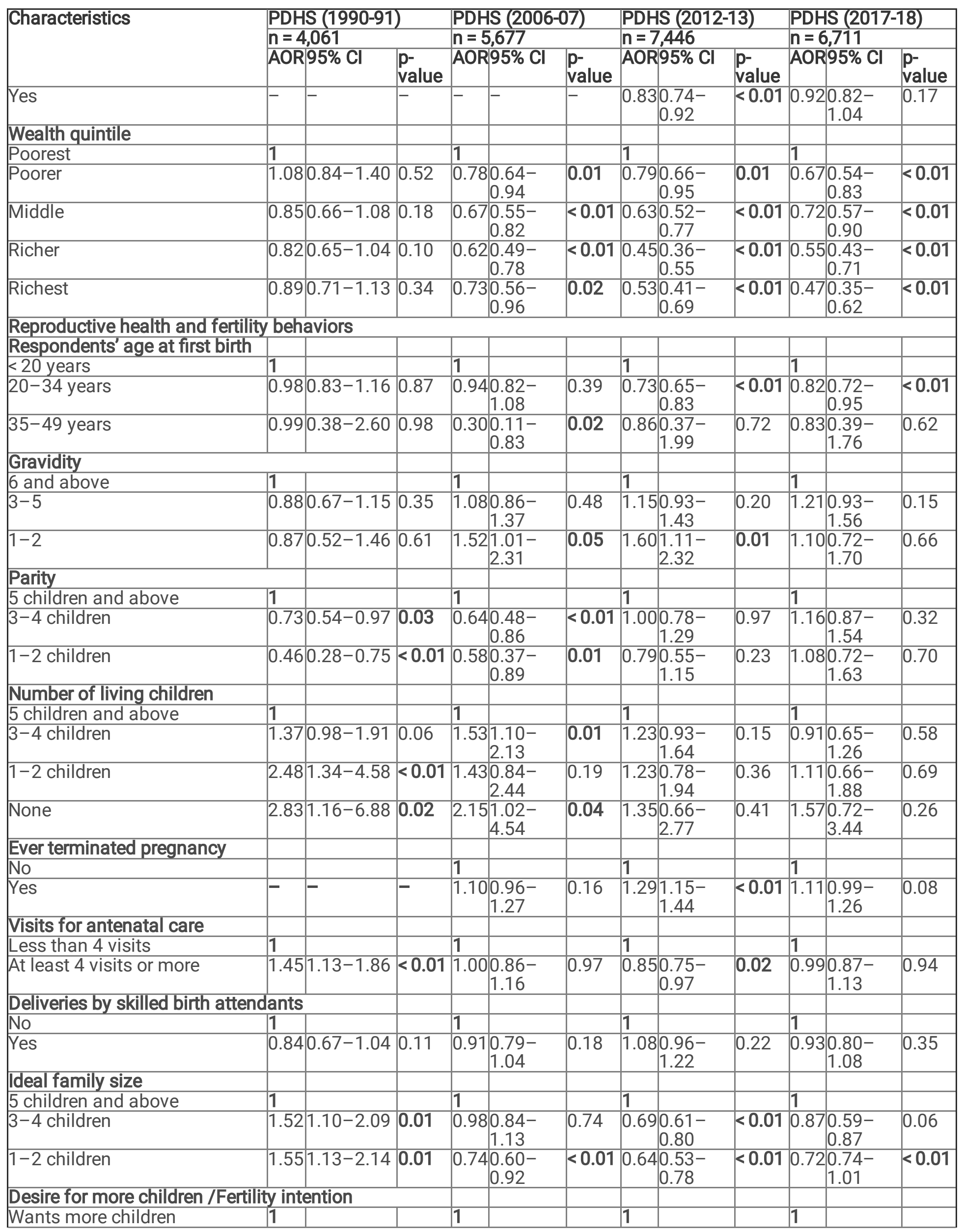




\begin{tabular}{|c|c|c|c|c|c|c|c|c|}
\hline \multirow[t]{3}{*}{ Characteristics } & \multirow{2}{*}{\multicolumn{2}{|c|}{$\begin{array}{l}\text { PDHS (1990-91) } \\
n=4,061\end{array}$}} & \multirow{2}{*}{\multicolumn{2}{|c|}{$\begin{array}{l}\text { PDHS (2006-07) } \\
n=5,677\end{array}$}} & \multirow{2}{*}{\multicolumn{2}{|c|}{$\begin{array}{l}\text { PDHS (2012-13) } \\
n=7,446\end{array}$}} & \multirow{2}{*}{\multicolumn{2}{|c|}{$\begin{array}{l}\text { PDHS (2017-18) } \\
n=6,711\end{array}$}} \\
\hline & & & & & & & & \\
\hline & AOR $95 \% \mathrm{Cl}$ & $\begin{array}{l}\text { p- } \\
\text { value }\end{array}$ & AOR $95 \% \mathrm{Cl}$ & $\begin{array}{l}\mathrm{p}- \\
\text { value }\end{array}$ & AOR $95 \% \mathrm{Cl}$ & $\begin{array}{l}\text { p- } \\
\text { value }\end{array}$ & AOR $95 \% \mathrm{Cl}$ & $\begin{array}{l}\text { p- } \\
\text { value }\end{array}$ \\
\hline Wants no more & $1.281 .08-1.52$ & $<0.01$ & \begin{tabular}{l|l}
1.03 & $0.88-$ \\
1.20
\end{tabular} & 0.69 & \begin{tabular}{c|l}
1.03 & $0.89-$ \\
& 1.18
\end{tabular} & 0.66 & $\begin{array}{c}0.900 .78- \\
1.04\end{array}$ & 0.16 \\
\hline \multicolumn{9}{|c|}{ Current use of contraception } \\
\hline No & 1 & & 1 & & 1 & & 1 & \\
\hline Yes & $0.840 .67-1.05$ & 0.13 & $1.04\left[\begin{array}{l}0.91- \\
1.19\end{array}\right.$ & 0.59 & $\begin{array}{c}1.060 .95- \\
1.19\end{array}$ & 0.29 & $\begin{array}{c}0.900 .81- \\
1.04\end{array}$ & 0.17 \\
\hline
\end{tabular}

